\title{
The livelihood impacts of oil palm Smallholders in Indonesia
}

\author{
Journal Article \\ Author(s): \\ Rist, Lucy; Feintrenie, Laurène; Levang, Patrice \\ Publication date: \\ 2010 \\ Permanent link: \\ https://doi.org/10.3929/ethz-b-000016972 \\ Rights / license: \\ In Copyright - Non-Commercial Use Permitted
}

Originally published in:

Biodiversity and Conservation 19(4), https://doi.org/10.1007/s10531-010-9815-z 


\title{
The livelihood impacts of oil palm: smallholders in Indonesia
}

\author{
Lucy Rist $\cdot$ Laurène Feintrenie $\cdot$ Patrice Levang
}

Received: 2 September 2009/Accepted: 13 February 2010/Published online: 3 March 2010

(C) Springer Science+Business Media B.V. 2010

\begin{abstract}
The biodiversity and climate consequences of oil palm (Elaeis guineensis) expansion across South East Asia have received considerable attention. The human side of the issue, highlighted with reports of negative livelihood outcomes and rights abuses by oil palm companies, has also led to controversy. Oil palm related conflicts have been widely documented in Indonesia yet uptake by farmers has also been extensive. An assessment of the livelihood impacts of oil palm development, including sources of conflict, is needed to shed light on the apparent contradiction between these reports and the evident enthusiasm of farmers to join the oil palm craze thereby informing future expansion. We assessed the impact of oil palm development on the economic wellbeing of rural farmers in Indonesia. We found that many smallholders have benefited substantially from the higher returns to land and labour afforded by oil palm but district authorities and smallholder cooperatives play key roles in the realisation of benefits. Conflicts between communities and companies have resulted almost entirely from lack of transparency, the absence of free, prior, and informed consent and unequal benefit sharing, and have been exacerbated by the absence of clear land rights. We make specific recommendations to improve the present situation and foster the establishment of smallholder friendly production regimes. Oil palm expansion in Indonesia is set to continue. If environmental standards can be raised and policy interventions targeted at the broader social impacts of land development this expansion may be achieved to the significant benefit of large numbers of rural smallholders.
\end{abstract}

Keywords Agriculture · Agroforestry · Elaeis guineensis · Income ·

Land tenure $\cdot$ Livelihood $\cdot$ Oil palm $\cdot$ Rubber $\cdot$ Rural development $\cdot$ Shifting cultivation

L. Rist $(\bowtie)$

Institute for Terrestrial Ecosystems, Ecosystem Management, ETH Zurich, 8092 Zurich, Switzerland e-mail: lucy.rist@env.ethz.ch

L. Feintrenie · P. Levang

Institut de Recherche pour le Développement, Boulevard de Dunkerque CS 90009, 13572 Marseille, France

L. Feintrenie · P. Levang

Centre for International Forestry Research, Bogor, P.O. Box 0113 BOCBD, Bogor 16000, Indonesia 


$\begin{array}{ll}\text { Abbreviations } \\ \text { CPO } & \text { Crude palm oil } \\ \text { FFB } & \text { Fresh fruit bunches } \\ \text { NAV } & \text { Net added value } \\ \text { NGO } & \text { Non governmental organisation } \\ \text { NES } & \text { Nucleus estates and smallholder } \\ \text { NTFP } & \text { Non timber forest product } \\ \text { RSPO } & \text { Roundtable on sustainable palm oil }\end{array}$

\section{Introduction}

During the past few decades, the oil palm (Elaeis guineensis) has become one of the most rapidly expanding equatorial crops in the world, the total cultivated area now accounting for nearly one-tenth of the world's permanent cropland (FAO 2007; WRI 2007). Cultivation in Indonesia increased from 3.6 million hectares (ha) in 1961 to 8.1 million ha in 2009 , the country now being the world's leading producer of palm oil with 19.2 million tons of CPO in 2008 (Ministry of Agriculture of Indonesia 2009). Despite a recent fall in the price of palm oil, prices are already recovering and growth in global demand is predicted to return to earlier levels of 2.2 million tons per year by 2010 (Index Mundi 2009; USDA-FAS 2009). Commercial production originated with Dutch colonial plantations on the island of Sumatra, which continues to account for $80 \%$ of total Indonesian production. In recent years oil palm has expanded in more remote locations on the islands of Kalimantan, Sulawesi and Papua (USDA-FAS 2009). Currently Indonesia has a total of 5.2 million hectares under production (Ministry of Agriculture of Indonesia 2009) and almost 20 million earmarked by local governments for potential future expansion (SawitWatch 2005; Wakker 2006). Additionally, Indonesian national policy currently seeks to expand palm oil-based biodiesel production capacity from 600 million litres to 3 billion litres by 2017 (OECD-FAO 2008) and the national government has plans to invest US $\$ 1.1$ billion to develop up to eleven additional palm oil-based biodiesel plants by 2010 (Armbruster and Coyle 2006). With growing demand for both food and fuel export, as well as for domestic biodiesel production, it is likely that significant further land use conversion to oil palm will occur (Koh and Wilcove 2007; Levang et al. 2008). Present plans are to increase production up to 40 million tons of CPO by 2020 (Ministry of Agriculture of Indonesia 2009).

The rapid and massive expansion of oil palm in the tropics, as well as other biofuels, has led to concern over impacts on natural habitats, biodiversity and the global climate (Fargione et al. 2008; James 2008; Koh and Ghazoul 2008; Butler and Laurance 2009). While this has been paralleled by alarm over the implications for national and global food security (Rahman et al. 2008) the broader social and livelihood implications of biofuel cultivation remain poorly understood (Sandker et al. 2008; CIFOR 2008, Rist et al. 2009). Several NGO reports have highlighted significant negative impacts on rural communities, incidents of human rights violations and 'land grabbing' in areas of oil palm development (WRM 2001; Colchester and Jiwan 2006; Colchester et al. 2007; FOE 2008). Oil palm has been accused of negatively affecting human health, destroying cultural heritage and leading to the loss of autonomy and self sufficiency, in addition to impoverishment as a result of debts and low wages (FOE 2008). 
Contrary to these reports, oil palm appears to be an attractive new income opportunity to Indonesian farmers, as attested by the widespread uptake by many smallholder communities (Eye on Aceh 2007). The Indonesian government has used oil palm as a major vehicle for rural socio-economic improvement (Potter and Lee 1998; Zen et al. 2005). This has been done largely through Nucleus Estate and Smallholder schemes (NES). In these schemes farmers transfer a proportion of their land to an oil palm company for establishment of an estate plantation (referred to as 'inti'); the remaining land is also planted by the company but retained as individual smallholdings by the farmers (referred to as 'plasma'). Typically households are asked to give up 10 ha of land to the company, and in compensation are allocated 2 ha of oil palm plantation. Once the smallholder receives his plot, he can either manage it by himself or entrust it to the company. Where smallholders cannot allocate a sufficient portion of land they must repay smallholding establishment costs to the company. In some cases smallholders sell their land directly to the company and are paid compensation for loss of land use opportunities. One third of the current area under oil palm in Indonesia is cultivated by smallholders, approximately 2.4 million ha (Ministry of Agriculture of Indonesia 2009) and much of the expected future expansion will occur as a consequence of smallholder uptake (Vermeulen and Goad 2006; CIFOR 2008). As such it is necessary that we have a greater understanding of the current and potential future livelihood consequences of oil palm agriculture (Sandker et al. 2007). Assessment of empirical data on reported, and indeed other potential livelihood impacts, is required to shed light on the apparent contradiction between NGO claims of negative livelihood impacts and the evident enthusiasm of farmers for oil palm.

We present information from assessment of the livelihood outcomes of oil palm agriculture at several locations in Indonesia. Land use decisions in the context of oil palm are made predominantly on the basis of financial capital therefore we focus this livelihood assessment on economic wellbeing (Potter and Lee 1998). We recognise that other important issues relating to livelihood security include health, social networks, and the loss of environmental goods and services. However these issues are beyond the scope of this paper. We consider the implications of oil palm as an alternative land use for smallholder income. We assess the positive impacts from development as well as sources of conflict, identify common factors behind these divergent outcomes and generate policy recommendations for moving towards more socially sustainable oil palm development within Indonesia. We focus on outcomes for NES and independent oil palm smallholders rather than employees of plantations or processing units.

\section{Methods and study locations}

The Center for International Forestry Research (CIFOR), Indonesia and the Institut de Recherche pour le Développement (IRD), France have a long research presence in several transmigration areas in Sumatra and Kalimantan spanning periods of oil palm development. Studies in these locations have assessed factors behind conversion decisions by smallholders and have investigated the implications of development for economic wellbeing. We focus on household socioeconomic data gathered from Bungo district in the province of Jambi, Sumatra between 2007 to 2009 and draw upon evidence from additional surveys and field documentation in three other provinces, namely West, Central and East Kalimantan. Full details of the socioeconomic methodologies used have been detailed elsewhere (see Feintrenie and Levang 2009; Feintrenie et al. 2009). We build on these socioeconomic studies, and draw upon observations made over longer timescales in these 
locations, synthesizing these findings to draw general conclusions on the livelihood impact of oil palm development at these locations.

Information on the growing economic aspirations of communities in the context of local development opportunities is presented along with attitudes towards the opportunities afforded by oil palm. The impacts of adoption on economic wellbeing are assessed, in particular the influence of debts for smallholding establishment under various scenarios and development schemes. Using socioeconomic data gathered from Bungo, the profitability of oil palm in comparison to alternative sources of agricultural income is investigated. Additional factors influencing the land use choices of farmers are also considered. Finally observations across the four locations are drawn upon to identify several factors that emerge repeatedly as sources of conflict in oil palm development.

\section{Bungo, Central Sumatra}

Bungo district is located next to the Kerinci Seblat National Park in the province of Jambi. Similar to many other districts in Sumatra, land use and the economy of Bungo remain strongly agricultural; slightly more than half being used for agriculture (BAPPEDA and BPS 2006). Forty four percent remains forested and under the control of the Ministry of Forestry. Coal mining in the area is growing rapidly (Profil Daerah 2006). The first plantation was developed under a transmigration program in 1988 and has expanded to 10,265 ha of estates, 20,492 ha of estate-linked smallholdings and 2,085 ha of independent production (BPS Bungo 2007). Four oil palm refineries share a total processing capacity of 240 tonnes of CPO per hour (BPS Bungo 2007). Lowland rice remains the main food crop system and absorbs much rural labour, particularly of women. Previously communities combined exploitation of rattan and natural rubber (as well as Palaquium spp., Dyera costulata and Ficus elastica), with upland rice cultivation. Oil palm and monoculture rubber have now partially replaced rubber agroforestry in the district and forest dependency has decreased significantly (Feintrenie and Levang 2009).

\section{Sanggau, West Kalimantan}

Sanggau has the largest area of oil palm in West Kalimantan (BPS 2006). Beginning with a state owned company in 1979, oil palm has now become one of the main foci for investment and business expansion. Population density has increased dramatically with the influx of large numbers of transmigrants and spontaneous migrants in the 1980s and 90s. People remain dependent on forests only in the remotest areas. Similar to Jambi, mining is now a major economic activity. The cultivation of cocoa, pepper and coconut are also significant (Colchester and Jiwan 2006).

\section{Northern Barito, Central Kalimantan}

Quite remote until recently, Northern Barito has now become a popular destination for oil palm and coal mining companies. The area is characterized primarily by swidden (shifting) agriculture with some rubber agroforestry. Parts of the district remain isolated with communities highly dependent on forests and forest products. Such dependency decreases in areas benefiting from road infrastructure. In the more accessible parts, population density has also grown with the arrival of spontaneous migrants from Java. 
Malinau, East Kalimantan

Malinau is a heavily forested region in the northern part of East Kalimantan. Patches of swidden cultivation and secondary regrowth occur in a landscape dominated by primary forest. Population densities are low and local communities remain highly dependent on forest resources. Oil palm is not yet in the area but the district government has been approached by oil palm companies as well as by the pulp and paper industry for the development of tens of thousands hectares. Most oil palm projects have been postponed due to the recent decline in CPO price.

\section{Results}

Strong desire but limited opportunities for development

In all four locations communities were eager for economic development. In remote locations such as Malinau, villages compete to lure investors such as logging companies, coal miners and oil palm developers. In our experience cases where a village resists such investment are rare and yet often disproportionately publicized. For example, one village which refused nine offers by a logging company has received significant attention while the numerous deals between communities and loggers in the rest of the district (more than 50) have not been mentioned in the same reports (CIFOR 2003). In areas such as Bungo where rubber or other agroforestry is already dominant, villagers frequently cited a desire for oil palm to reach their communities. For example, in a perception survey carried out in 12 villages in Bungo in 2007 we found that the majority of villagers expected, and indeed hoped, that oil palm and rubber would dominate land devoted to perennial cash crops over the next 20 years (Therville et al. in press). This was the case regardless of the present importance of oil palm in the village. In all locations, communities have growing monetary aspirations; desiring a regular source of income to secure greater access to education and health care as well as to purchase motorbikes or electronic goods. Indeed in Bungo, increased financial need was cited as the primary reason for conversion of agroforestry to oil palm.

While aspirations are growing there are few opportunities available for meeting these. In Malinau NTFP collection and shifting cultivation provide for subsistence but are seldom a regular source of monetary income. In the most remote areas of the district eaglewood collection was once lucrative but the attraction of large numbers of outsiders led to rapid exhaustion of the resource (Levang 2002). Currently only a few small groups of Punan hunter-gatherers rely on eaglewood collection for their monetary income. Other profitable opportunities like birds nest collection have also been appropriated by powerful local families or outsiders (Levang 2002). In the other sites, and indeed in most forested areas of Sumatra and Kalimantan, agricultural crops provide the main opportunity for enhancing cash income. Currently rubber (or sometimes rattan) agroforestry provide cash income but opportunities to expand production are frequently limited by lack of capital as well as time and labour constraints. Although land is plentiful, many farmers prefer to intensify production in their closest plots rather than expanding less profitable cropping systems, especially where land may be less accessible or more difficult to cultivate. Mast fruiting species such as Duku (Lansium domesticum) and Durian (Durio zibethinus) can generate substantial income but such income is unreliable being dependant on events that occur only once every few years (Bouamrane 1996). Logging in the past has been extensive. Lacking 
the equipment required to extract from more remote areas, timber now contributes little to these communities above subsistence needs.

Against this background, oil palm is widely considered by communities as the best option for meeting their financial needs. Farmers' only asset is their land (for which their rights are only informally recognised) and with low values in the absence of an established land market and companies willing to buy or rent this land (or swap 10 ha of bush fallow for 2 ha of oil palm plantation), many households are willing to do so, even at very low prices. In 2008 a respondent in Bungo district, along with fellow villagers, was about to sign a contract with an oil palm company handing over 10 ha of land in exchange of 2 ha of oil palm plantation and a small compensation in cash. He was told by field researchers that this deal was unfair and that he could get much better terms if he waited until the following year. The road was under construction and competition among companies was certain to increase when completed leading to better deals for the villagers. He did not want to listen arguing that he had been waiting for too long for a company to come. He said: "I want to change my fate now! I own plenty of land which has no value. With oil palm I'll get a regular income, with the company doing all the work".

The consequences of oil palm development for economic wellbeing

While detailed legislative processes govern the location of oil palm development in Indonesia, the means by which this occurs, i.e. the particular deals offered to communities, vary significantly. Variation in the amount of land given up to the company in relation to that received back as an oil palm smallholding, the amount of debt that the farmer must pay back for the planting of oil palm on the area of land retained, as well as the time period over which this must be done were the main factors characterising variation in deals within and across our study sites and their associated financial outcomes (Table 1). Specifically in relation to debts for set up costs, the value of the initial debt estimated by the company, the rate of interest applied by the bank, and the percentage of monthly 'Net Added Value' (NAV), or net income that smallholders agree to allocate to the reimbursement of their debt are key factors (Chong 2008).

However we found that where development schemes were rather similar (benefit sharing and price setting) the livelihood outcomes were often very different. Although we found similar schemes in villages in Kalimantan, many farmers had not experienced the positive impacts of oil palm development that were common in Bungo (Gaiser 2009; Orth 2009). We found that farmers frequently sold their land to companies rather than developing a smallholding leaving them without a source of agricultural income, or with such income significantly reduced. Alternatively the short term horizon of some farmers meant that while they developed an oil palm smallholding they gave up in the first years following planting, selling off the land and the oil palm before it reached production (Gaiser 2009; Orth 2009). The cost of fertiliser was frequently cited as a reason for this along with a dislike of living in a new plantation village far from relatives (Feintrenie, unpublished data). Many believe that they can return to their village and resume their former life only later discovering that they have little land left and can no longer clear new swiddens from the forest (Orth 2009).

Farmers generally gave up their fallow or less productive land to oil palm, in most cases old rubber agroforests that are no longer considered profitable (Chong 2008). Consequently former sources of income are rarely displaced and the income from oil palm may be considered as complementary to these, although the development of these fallows likely results in the loss of some environmental goods and services. A potential problem may come however with the debt incurred by conversion and maintenance. Oil palm deals have been 
Table 1 Variation in oil palm development schemes and implications for key variables influencing livelihood outcomes

\begin{tabular}{|c|c|c|c|c|c|c|c|}
\hline \multirow[t]{2}{*}{ Deal characteristics } & \multicolumn{7}{|c|}{$\begin{array}{l}\text { Oil palm development regimes (land to company: land retained by } \\
\text { smallholder) }\end{array}$} \\
\hline & 100:0 & $80: 20$ & $70: 30$ & $\begin{array}{l}70: 30 \text { with } \\
\text { transmigration }\end{array}$ & $60: 40$ & $0: 100$ & $\begin{array}{l}\text { Independent } \\
\text { smallholding }\end{array}$ \\
\hline \multicolumn{8}{|l|}{ Land tenure ${ }^{\mathrm{a}}(\%)$} \\
\hline Smallholders in plasma & 0 & 20 & 30 & 30 & 40 & 100 & 100 \\
\hline Estate (init) & 100 & 80 & 70 & 30 & 60 & 0 & 0 \\
\hline Transmigrants & & & & 40 & & & \\
\hline \multicolumn{8}{|c|}{ Income and debt (smallholding of 2 ha) } \\
\hline Total debt (\$) & NA & 0 & \multicolumn{4}{|c|}{ Planting costs (about $\$ 1470$ ) } & Variable \\
\hline Commencement of repayment & NA & & \multicolumn{4}{|c|}{5 th year } & NA \\
\hline Monthly repayment (\% NAV) & NA & 0 & \multicolumn{4}{|l|}{30} & NA \\
\hline Payback time & NA & & \multicolumn{4}{|c|}{9.5 years } & \\
\hline $\begin{array}{l}\% \text { Income generated by } \\
\text { smallholding and received by } \\
\text { the smallholder }\end{array}$ & 20 & \multicolumn{6}{|c|}{100 (after repayment of planting debt) } \\
\hline \multicolumn{8}{|l|}{ Management responsibility } \\
\hline Infrastructure & \multicolumn{6}{|l|}{ Company } & Company \\
\hline Planting & \multicolumn{6}{|l|}{ Company } & Smallholder \\
\hline Plantation management & Company & \multicolumn{5}{|c|}{ Koperasi plasma (smallholders cooperative) } & Smallholder \\
\hline
\end{tabular}

${ }^{a}$ This land is sold and lost permanently

criticized as being unfair to smallholders with planting and management costs creating high levels of debt, sometimes too high to be repaid by smallholders during the production period (FOE 2008). However, we heard such complaints from smallholders only in the first years of repayment when production was low or during the recent decline in CPO prices. Using data from Bungo, debt repayment periods for smallholders were calculated under the variety of scenarios present in the district (Feintrenie et al. 2009). Typical conditions are a 2 ha smallholding, a loan of about 15 million Indonesian Rupiah (Rp) (1,470 US\$), an interest rate of $14 \%$ and a reimbursement of $30 \%$ of the monthly NAV with repayment beginning in the 5th year after planting. With these contract conditions and using the high price of FFB common until July 2008 (1,500 Rp/kg), smallholders could pay off their debt in less than 6 years (Feintrenie et al. 2009). In fact some smallholders in Bungo choose to repay faster committing $60 \%$ of NAV to debt repayment, at this rate smallholders would pay off their debt in less than 3 years (Feintrenie, unpublished data). Since July 2008 FFB price has fallen to about $800 \mathrm{Rp} / \mathrm{kg}$ and there has been concern about the consequences of such price fluctuations on smallholders. Using the same interest rate and debt repayment schedule, at the low price a smallholder would need 12.5 years to repay his debt. With reimbursement starting in the fifth year, the smallholder would be freed of his debt only once the plantation reaches 18 years, while oil palms are usually cut after 25 years.

The economics of land use

We compared the profitability of oil palm at high and low prices with alternative sources of agricultural income, namely rubber agroforestry, clonal rubber and inundated rice. Initial 
investments including debt repayment for oil palm development, as well as the cost of regular inputs such as fertiliser were included in the calculations (Feintrenie et al. 2009). Although clonal rubber generates the highest returns to land, at high prices oil palm comes out on top in terms of returns to labour (Table 2). This is mainly due to the very low labour requirements associated with harvesting; farmers report oil palm to be less work than alternative agricultural land uses, specifically rubber ( 2 days labour per month in comparison to 14). In Bungo, as in many areas of Indonesia where oil palm development is occurring, land is in plentiful supply therefore returns to labour have the greatest influence on decision making. Additional factors explained farmers' preference for oil palm. The short time period ( 3 years) between planting and first harvest (Table 2) was cited by many villagers as a significant benefit of conversion, as was the fact that conversion results in land titling and sharing of the management burden with the oil palm company (Feintrenie et al. 2009).

While the recent drop in CPO price (accompanied by a similar drop for natural rubber) has reduced smallholder income from oil palm many farmers said they would continue to plant both rubber and oil palm. Farmers mentioned specific complementarities between rubber and oil palm as justification for this. Rubber is usually harvested in the dry season as rain interferes with the collection of the latex whereas oil palm can be harvested year round. CPO price is already recovering and in fact the crisis appears to have promoted oil palm in some locations; farmers have recognised the quick recovery of CPO price in comparison with rubber as a significant benefit. By June 2009 cooperative members in Bungo had already recovered previous levels of monthly income from oil palm while many rubber smallholders were facing significant economic difficulty (Feintrenie, unpublished data). We found that those farmers seriously affected by the drop in CPO price were those saddled with significant debts from the conversion of large land areas. Wealthier farmers convert up to 10 ha or more and appear to be those who suffered the greatest impact from the crisis.

In Barito we found that some communities were unwilling to venture into oil palm. These communities live in the most remote parts of the district, are highly forest dependant and do not own any rubber or rattan plantations (Orth 2009). Where people have 'pure' swidden and no experience of plantations they appear less well prepared for oil palm. In addition some had contact with downstream villages where previous land development by companies had led to the exclusion of smallholders. Communities reported that this information led them to resist any attempt by oil palm companies to buy land in their area. In Sanggau we found great variation in villagers' attitudes toward oil palm depending on

Table 2 Profitability of the main agricultural systems in Bungo District, Sumatra

\begin{tabular}{lllll}
\hline & Oil palm & Clonal rubber & Rubber agroforest & Inundated rice \\
\hline $\begin{array}{l}\text { Immature period (years) } \\
\text { Farm gate prices in 2007-2009 }(\$ / \mathrm{kg})\end{array}$ & 5 & $10-15$ & 0 \\
High & 0.18 & 0.98 & & 0.98 \\
Low & 0.08 & 0.49 & 0.49 & 0.49 \\
Yearly return to land (\$/ha) & & & & 264.51 \\
Average (high price) & 2846.36 & 3590.48 & 1548.77 & 2.27 \\
Yearly return to labour (\$/man day) & & & 29.05 \\
Average (high price) & 47.33 & 24.39 &
\end{tabular}


their own previous experience with companies (Gaiser 2009). Developments occurring during the Suharto rule were often unfavourable to local smallholders. With the fall of Suharto in 1998 and the subsequent 'reformasi' period, conditions changed significantly with strengthened communities rights and consequently the ability to resist land development. Despite this many communities remain cautious. Such decision making based on negative reports from neighbouring communities, or 'pre-reformasi' experience of oil palm development appears to be common in other sites across Indonesia (CIFOR 2000).

\section{Conflicts and missed opportunities}

Several factors emerged repeatedly across the study locations as sources of conflict following plantation development; the clarity of the contracts signed with companies, weak local governance, the failure of companies to meet either contractual or perceived obligations, lack of clarity over land tenure prior to plantation development and changing land values.

\section{Clarity of development contracts}

We rarely encountered a farmer who had actually read the contract that he had signed. Those that had were seldom able to understand the wording used and relied instead on verbal agreements with local officials. When contractual terms were later under question the main points of uncertainty related to who retained ownership of the land and the terms of debt repayment. Typically the company 'takes' the land for an oil palm cycle but what happens after this period is unclear and rarely specified in the terms of the contract. In relation to the debt incurred for planting of the smallholding, many farmers do not know how much they owe the company, or how this payment is calculated (Chong 2008).

\section{Local governance and unfulfilled promises}

Both companies and local government officials made promises that were not fulfilled and hence became a source of conflict. Commonly companies failed to meet the terms of community agreements, particularly in the development of schools and clinics or the provision of technical assistance in plantation management (FOE 2008). Local officials have a vested interest in ensuring that oil palm development goes ahead; taxes on agricultural products and enhanced district authority over agricultural land, as well as bribes and financial support during electoral campaigning make oil palm development highly desirable to them. As a result, development agreements with the community are rushed through without the concurrence of the company to verbal promises made by the officials. When problems arise at a later stage the officials have often moved on to another official position and are no longer accountable. Farmers feel that they have been cheated and blame the company for unmet promises.

In one village in Bungo a new oil palm transmigration project was launched in 2004. Villagers agreed to participate in the project giving up a total of about 1,000 ha of land for its implementation. This land was to provide for oil palm as well as for the transmigrants that would join the scheme. As compensation, an equal number of local households were to be included in the project. The transmigrants recruited in Jakarta arrived in 2004 and 2005, but the oil palm company never followed (Adnan and Yentirizal 2007). Both local people and the migrants are still waiting. In 2008 some migrants independently began planting oil palm. By this time the local people considered that the promises made to them had not been 
kept and wanted their land returned culminating in the burning of many areas planted by migrant families (Feintrenie et al. 2009). This conflict was not the result of oil palm development per se but bad governance of a rural development project. The district government, keen to secure the benefits associated with oil palm development settled Javanese migrants on local communities' lands before securing the participation of a company. Although plantations have recently been developed close by, the area itself is very hilly and will require major land preparation before being suitable for oil palm.

While many farmers adopting oil palm have experienced an increase in economic wellbeing, in some locations these benefits have been considerably lower. In particular we have observed the significant impact that the 'ketua koperasi', the manager of the smallholders' cooperative, can have on the success of individual development schemes. Some play a key role in maximising the benefits to smallholders, negotiating both better prices and holding companies to their contractual responsibilities. Others use the position for personal gain obtaining company bribes for arrangements which favour the company over smallholders.

\section{Unclear land tenure}

We have also observed several conflicts relating to land tenure including the handing over by local government of traditional common land to oil palm companies or to transmigrants. Cases of land owners accusing companies of stealing their land are not uncommon; however some are not adequately justified. On investigation of some of these 'land grabbing' claims in Barito it became clear that land had been legally sold to the accused company and the proceeds pocketed by family members (Orth 2009). In this particular village the company has an ongoing conflict with 60 families. It appears that family members with connections to the local authorities sold land to the company without notification of those now contesting ownership. These villagers had certainly been cheated but preferred to blame the company rather than their relatives or village elites, doing so might be detrimental to social bonds. The company is willing to go to court arguing that it has proof of payment and a strong case. The farmers continue to complain but have not pursued legal action.

\section{Changing land values}

In another village in Bungo $80 \%$ of farmers sold their land when oil palm arrived in 1997. Each sold at Rp 200,000 (US\$69) per hectare. Today, the current land price in this area is approximately ten times higher and many farmers express deep regret over their decision. In several villages we have found similar situations and farmers who claim that they were cheated by companies. Companies have proof of payment; the amounts paid being appropriate to the land value at the time. As land values rise in response to the improved local infrastructure which accompanies oil palm development, farmers see others receiving significant sums for their land and feel that they were deliberately cheated by the company (Orth 2009).

\section{Discussion}

Livelihood benefits of oil palm development

Many NGOs have taken a strong position against oil palm development in Indonesia on the basis of its negative social impacts. The results of our work in Sumatra and Kalimantan 
suggest that oil palm has in fact been a source of significant livelihood improvement for many rural communities. Oil palm offers greater returns to labour than other agricultural land use options as well as additional benefits including a shorter fallow period and significantly reduced labour requirements. Susila (2004) found that oil palm activities contribute 5-11 million Rp (\$500-1000) or over 63\% of smallholder household incomes in two locations in Sumatra, and considered the small proportion of poor people $(<10 \%)$ in oil palm communities at these sites indicative of the commodities' contribution to poverty alleviation. Simulations of alternative future land use options in the district of Malinau in Kalimantan have also indicated potential improvements in household incomes of between 60 and $150 \%$ as a result of oil palm development (Sandker et al. 2007). However this simulation model did not take adequate account of oil palm production cycles, migration and its impact on local employment or local dependency on forest resources (Dudley et al. 2008). In Malaysia, the incidence of poverty among oil palm smallholders has been negligible since the early 1980s, compared to small-scale producers of other agricultural commodities such as fish and rice, among whom poverty has persisted (Simeh and Tengku Ahmad 2001). Our results provide further evidence for the potential for oil palm agriculture to enhance income in rural communities. Rural smallholders are not impoverished by oil palm development but can be by the sale of their land in its development. Legislation at the national level should continue to support smallholder development in order to capitalise on income benefits but should move towards a system of land rental rather than purchase.

Enhancing the social sustainability of oil palm production

Governance at the district and sub-district levels and specific characteristics of the development agreements between companies and communities play a key role in reducing the incidence of conflicts and maximizing livelihood benefits to smallholders. Similar conclusions have been drawn regarding the importance of these factors in other tenure and land use conflicts in Indonesia (Suyanto 2007; Adnan and Yentirizal 2007). These new insights, specific to oil palm, indicate significant opportunities for moving towards a fairer and more sustainable development regime and we offer four specific recommendations in this context:

(i) The clarification of smallholder land rights will be a pre-requisite in avoiding conflict between local communities and companies in the face of rising land values. The conventional view that farmers are powerless to act against aggressive expansion of oil palm is false (Chong 2008). Rather the inability to act against companies has occurred due to the lack of clear land rights and enforceable contracts, which are dependent on these rights.

(ii) We propose that significant reform and standardization of contracts for agreements between farmers and oil palm companies is needed at the district level. The current focus of certification bodies, namely the Roundtable for Sustainable Palm Oil (RSPO), on the development of national standards does not allow for sufficient flexibility to adjust to local conditions, or target those factors with the greatest influence on social outcomes. Significant variation exists between districts, particularly in terms of the level of competition among companies and consequently the bargaining power of the communities and officials. Districts also vary in customary rules, migrant-indigenous balance and gender representation in decision making, all 
with significant influence on development outcomes. The formulation of standard contracts within districts should involve industry and community representatives as well as local government in order to better address local conditions, yet should be formally supported by national law and current or future certification processes. Specifically these documents should outline the return of land to smallholders following the end of the first oil palm cycle and include a transparent breakdown of smallholding development costs and debt repayment schedules. A document widely recognised as standard and fair to both parties, akin to the regard held for the conventional property rental agreement would ensure that even if contracts are not read by farmers their rights have been formally protected and they can be properly enforced when disagreements arise. By developing standardised formal agreements to regulate the terms and benefit sharing associated with community involvement in oil palm development we believe the exercise of free, prior and informed consent (Colchester and Ferrari 2007) could be facilitated and a large amount of the variability and chance regarding outcomes for farmers removed.

(iii) In addition to development regime characteristics we found additional factors that had a significant influence on the relative economic benefits experienced by smallholders, specifically the extent and quality of extension service provision and the management capacity of the smallholders' cooperative. In particular the head of the district plays a key role in the negotiation of prices with companies. Such variability is also common in West Kalimantan (P. Gillespie, personal communication with LR). We suggest that respected customary leaders can play a key role in enhancing the capacity and functioning of smallholder associations, a role that might be facilitated by more active engagement of advocacy groups and NGO's with district authorities. While these groups have an important role in raising awareness in cases of coercion and unfair practices (as have certainly occurred in some locations in Indonesia, C. Colfer, personal communication with LR.), significant benefit could be achieved by drawing attention to the role of these key individuals allowing communities to remove from power those not adequately pursuing their collective interests. Currently the NGO approach has been of limited local effectiveness (in some cases even generating serious negative repercussions for communities, including imprisonment for damage to company property (P. Gillespie, personal communication with LR) and internationally has ended up generating boycotts of oil palm products which are detrimental to those that their campaigns aim to defend (Mongabay 2008; Wilson 2009).

(iv) Finally, governments at the national and district level should promote further oil palm development via individual smallholdings rather than large agribusiness. Companies can play a key role in palm oil processing which, combined with smallholder production, would maintain a high quality product from a more socially and environmentally friendly system of production. The need for more decentralized and diversified systems of production and processing has already been emphasized (Belcher et al. 2004) and in some locations smallholders have moved towards more diverse production systems against company development plans in order to better meet their own needs (Potter and Lee 1998). Assessment of the economics of alternative production models is needed to assess their financial viability and social sustainability. Certification bodies such as RSPO have an important role to play in providing incentives for smaller scale diversified production systems. 
The wider livelihood impacts of oil palm development

The cultivation of oil palm may afford new income opportunities to many Indonesian farmers but while economically advantageous in the short term, the longer term economic implications remain uncertain. Concerns have been raised that the adoption of oil palm by smallholders at the expense of, for example, diverse agroforestry and swidden systems may expose them to future economic risk from price fluctuations (Butler et al. 2009; Syafriel 2009; C. Colfer, personal communication with LR). Our observations suggest that such concerns may not be fully justified, and in fact in some locations oil palm has mitigated exposure to such variation by reducing dependence on rubber as a single cash commodity (Feintrenie and Levang 2009). Indeed we found little evidence to suggest that decision making regarding land use allocation had been altered significantly by recent declines in CPO price. However, such resilience will be afforded by secure land ownership; the impacts of price variability on transmigrant farmers who with limited land have no opportunity to diversify are likely to be significantly different (Zen et al. 2005). Aging oil palms become difficult to harvest and decline in productivity (Potter and Lee 1998) and the renewal of plantations at the end of the productive cycle represents a significant financial burden which has not been investigated. The land must be machine ploughed at significant cost and there is evidence that long term soil fertility may be affected (Jacquemard 1995). In locations where land is less abundant and its limited availability exacerbated by population growth, this may have significant consequences in the longer term.

Our study considered impacts on financial assets, specifically income. Although certainly a high priority for many smallholders, income is just one component of sustainable livelihoods (Carney 1999) and oil palm may have many additional direct and indirect livelihood impacts. Although less productive land is often used for development these fallows provide many environmental goods and services. In more remote areas where livelihoods are largely subsistence-based the consequences may be more significant than in the sites with which we have most experience. Negative implications for cultures and ways of life in moving from autonomous farming to a market dependant livelihood, or in some cases to wage labour, are also likely (C. Colfer, personal communication with LR). Plantations have further impacts on communities not directly involved but living adjacent to areas of oil palm development. For example, the pollution of air or water courses (McCarthy and Zen 2010). Increasing rat populations associated with plantations have also decimated adjacent rice farms in some areas of West Kalimantan (P. Gillespie, personal communication with LR). Incorporating the assessment and mitigation of such negative livelihood impacts into future oil palm development schemes and certification efforts will be a further challenge.

The full livelihood impacts on rural communities involved in oil palm cultivation, particularly those on food security, health, social and cultural change, and the loss of environmental goods and services remain little understood (except see Casson 2000; Koczberski et al. 2001; Belcher et al. 2004; Colchester and Jiwan 2006) and further research is urgently needed to address these issues. One of the main obstacles in this endeavour will be accurately assessing how local people may value the non-monetary losses that they may experience as a result of oil palm development, and how they are willing (or not) to trade these off against greater income. In our experience it has been clear that people want development but they continue to value the services and goods provided by a forested landscape. Reconciling these two desires will be a considerable challenge but one that is fundamental to improving livelihoods and conserving biodiverse forest landscapes. 


\section{Conclusion}

Oil palm development in Indonesia has provoked a huge amount of controversy. While the potential developmental benefits of biofuel cultivation have been emphasized (Nature 2007; Pickett et al. 2008), many have taken a strong position against plantation expansion for social as well as environmental reasons. There is now little doubt that unregulated oil palm expansion poses a serious threat to tropical ecosystems, biodiversity and potentially the global climate (Koh and Wilcove 2007, 2008, 2009; Koh and Ghazoul 2008; Fitzherbert et al. 2008; Fargione et al. 2008). Uncontrolled expansion will also have serious implications for many rural communities, yet with new production models there is significant potential for reducing many sources of conflict and capitalising on the development benefits. While acknowledging the serious environmental implications of oil palm expansion in Indonesia, and additionally the livelihood consequences of such impacts, future expansion is probably inevitable. If this can be driven down a more socially sustainable path it may hold significant potential to support rural development in some locations. The question is not one of oil palm or not, but of how can we maximise the development benefits while minimising the negative social and environmental impacts; we must continue to look for alternative production scenarios that allow ecologically and socially sustainable oil palm development.

Acknowledgments We are grateful to John McCarthy, Piers Gillespie, Nina Gaiser, Clara Therville, Chong Wan Kian, Ameline Lehébel-Péron, Xavier Bonnart and Meri Orth for sharing their insights from the field. Carol Colfer provided stimulating discussion and many comments on an earlier draft which greatly improved the manuscript.

\section{References}

Adnan H, Yentirizal (2007) Blessing or misfortune? locals, transmigrants and collective action. CIFOR Governance brief no. 36. CIFOR, Bogor, Indonesia

Anonymous (2007) Kill king corn. Nature 449:637

Armbruster WJ, Coyle WT (2006) Pacific food system outlook 2006-2007: the future role of biofuels. Pacific Economic Cooperation Council, Singapore

BAPPEDA, BPS (2006) Produk Domestik Regional Bruto PDRB 2002-2006. Kabupaten Bungo

Belcher B, Rujehan, Imang N, Achdiawan R (2004) Rattan, rubber or oil palm: cultural and financial considerations for farmers in Kalimantan. Econ Bot 58:77-87

Bouamrane M (1996) A season of gold-putting a value on harvests from Indonesian agroforests. Agrofor Today 8:8-10

Bungo BPS (2007) Bungo dalam angka 2006. Badan Pusat Statistik Kabupaten Bungo, Muara Bungo, Indonesia

Butler RA, Laurance W (2009) Is oil palm the next emerging threat to the Amazon. Trop Conserv Sci 2:1-10

Butler RA, Koh LP, Ghazoul J (2009) REDD in the red: palm oil could undermine carbon payment schemes. Conserv Lett 2:67-73

Carney D (1999) Approaches to sustainable livelihoods for the rural poor. ODI Poverty Briefing, ODI, London

Casson A (2000) The hesitant boom: Indonesia's oil palm sub-sector in an era of economic crisis and political change. Center for International Forestry Research, Bogor, Indonesia

Chong WK (2008) Oil palm development and land management in Bungo district, Jambi, Indonesia. MSc dissertation, University of Technology and Sciences, Montpellier

CIFOR (2000) Kabar dari. Tim pendamping pemetaan desa partisipatif hulu sungai Malinau. Center for International Forestry Research, Bogor, Indonesia

CIFOR (2003) CIFOR helps village win major environmental award p3-4 In CIFOR News 33. Centre for International Forestry Research, Bogor, Indonesia

CIFOR (2008) The impacts and opportunities of oil palm in Southeast Asia: What do we know and what do we need to know? Centre for International Forestry Research, Bogor, Indonesia 
Colchester M, Ferrari MF (2007) Making FPIC - free, prior and informed consent-work: challenges and prospects for indigenous peoples. Forest Peoples Programme, Moreton-in-Marsh, UK

Colchester M, Jiwan N (2006) Ghosts on our own land: Indonesian oil palm smallholders and the roundtable on sustainable palm oil. Forest Peoples Programme, and Perkumpulan Sawit Watch, Moreton-inMarsh, UK, and Bogor, Indonesia

Colchester M, Aik Pang W, Meng Chuo W, Jalong T (2007) Land is life: land rights and oil palm development in Sarawak. Forest Peoples Programme, and Perkumpulan Sawit Watch, Moreton-inMarsh, UK, and Bogor, Indonesia

Dudley RG, Sheil D, Colfer C (2008) Simulating oil palm expansion requires credible approaches that address real issues. Ecol Soc 13:r1. Available via http://www.ecologyandsociety.org/vol13/iss1/resp1/. Accessed 15 June 2009

Eye on Aceh (2007) The "Golden" Crop? Palm oil in post-Tsunami Aceh. Aceh: Eye on Aceh. Available via http://www.aceh-eye.org/data_files/english_format/ngo/ngo_eoa/ngo_eoa_2007_09_00.pdf. Accessed 15 June 2009

FAO (2007) FAOSTAT online statistical service. United Nations Food and Agriculture Organization (FAO), Rome. Available via http://faostat.fao.org. Accessed 15 June 2009

Fargione J, Hill J, Tilman D, Polasky S, Hawthorne P (2008) Land clearing and the biofuel carbon debt. Science 319:1235-1238

Feintrenie L, Levang P (2009) Sumatra's rubber agroforests: advent, rise and fall of a sustainable cropping system. Small-Scale For 8:323-335

Feintrenie L, Chong WK, Levang P (2009) How to influence oil palm development in order to make it benefit local people and prevent uncontrolled deforestation? Abstracts of the XIII World Forestry Congress, Buenos Aires, Argentina, 19-23 October 2009

Fitzherbert EB, Struebig MJ, Morel A, Danielson F, Brühl CA, Donald PF, Phalan B (2008) How will oil palm expansion affect biodiversity? Trends Ecol Evol 23:538-545

FOE (2008) Losing ground the human rights impacts of oil palm plantation expansion in Indonesia. Friends of the Earth, UK

Gaiser NM (2009) Perceptions of oil palm cultivation in West Kalimantan-local farmers between development, conservation and indigenous rights discourses. Dissertation, University of Freiburg, Germany

Index Mundi (2009) Available via http://www.indexmundi.com/commodities. Accessed 15 June 2009

Jacquemard JC (1995) Le palmier à huile. Le technicien d'agriculture tropical. Maisonneuve et Larose, Paris, France

James WE (2008) Food prices and inflation in developing Asia: Is poverty reduction coming to an end? Asian Development Bank, Philippines

Koczberski G, Gibson G, Curry K (2001) Improving productivity of the smallholder oil palm sector in Papua New Guinea: a socio-economic study of the Hoskins and Popondetta schemes. The Australian National University

Koh LP, Ghazoul J (2008) Biofuels, biodiversity, and people: understanding the conflicts and finding opportunities. Biol Conserv 141:2450-2460

Koh LP, Wilcove DS (2007) Cashing in palm oil for conservation. Nature 448:993-994

Koh LP, Wilcove DS (2008) Is oil palm agriculture really destroying tropical biodiversity? Conserv Lett 1:60-64

Koh LP, Wilcove DS (2009) Oil palm: disinformation enables deforestation. Trends Ecol Evol 24:67-68

Levang P (2002) Peoples' dependencies on forest. In forest, science and sustainability: the Bulungan Model Forest. Centre for International Forestry Research, Bogor, Indonesia

Levang P, Sheil D, Kanninen M (2008) Le palmier à huile, Dr Jekill pour l'énergie, Mr Hyde pour la biodiversité. Liaison énergie-francophonie Numéro Spécial pp 26-31

McCarthy J, Zen Z (2010) Regulating the oil palm boom: assessing the effectiveness of environmental governance approaches to agro-industrial pollution in Indonesia. Law and Policy 32(1):153-179

Ministry of Agriculture of Indonesia (2009) Keynote address at the MAKSI Conference, Bogor, November 24, 2009

Mongabay (2008) Palm oil boycott an unrealistic approach to conserving biodiversity. Available via http://news.mongabay.com/2008/0415-palm_oil_conservation.html. Accessed 15 June 2009

OECD-FAO (2008) Agricultural outlook 2008-2017. Organisation for Economic Co-operation and Development and Food and Agriculture Organization of the United Nations

Orth MG (2009) The Noble Savage Fancies Development. Determinants of community responses to forest conversion plans in Central Kalimantan, Indonesia. Dissertation, Technical University Dresden, Germany 
Pickett J, Anderson D, Bowles D, Bridgwater T, Jarvis P, Mortimer N, Poliakoff M, Woods J (2008) Sustainable biofuels: prospects and challenges. The Royal Society, London, UK

Potter L, Lee J (1998) Tree planting in Indonesia: trends, impacts and directions. Occasional paper no. 18. Centre for International Forestry Research, Bogor, Indonesia

Profil Daerah (2006) Kabupaten Bungo Tahun 2006. Kabupaten Bungo

Rahman SH, Ahmed AM, Bauer A, Bhushan I, Carrasco B, Chatterjee S, Dawson RLT, Fawcett B, Hussain A, James WE, Kannan K, Lin T, Mitra S, Olega A, Renfro RZH, Roche FC, Shrestha S, Siddiq A, Srinivasan R, Zahid SN, Zhuang J, Zhukov EG, Alamgir M (2008) Soaring food prices: response to the crisis. Asian Development Bank, Manila, Philippines

Rist L, Lee JSH, Koh LP (2009) Biofuels: social benefits. Science 326:1344

Sandker M, Suwarno A, Campbell BM (2007) Will forests remain in the face of oil palm expansion? Simulating change in Malinau, Indonesia. Ecol Soc 12:37. Available via http://www.ecologyand society.org/vol12/iss2/art37. Accessed 15 June 2009

Sandker M, Campbell BM, Suwarno A (2008) What are participatory scoping models? Ecol Soc 13:r2. Available via http://www.ecologyandsociety.org/vol13/iss1/resp2 . Accessed 15 June 2009

SawitWatch (2005) Briefing paper following second meeting of RSPO Criteria Working Group. Available via http://www.forestpeoples.org/documents/prv_sector/oil_palm/rspo_feb05_briefing_eng.shtml. Accessed 15 June 2009

Simeh A, Tengku Ahmad TMA (2001) Regional workshop on commodity export diversification and poverty reduction in South and South-East Asia: the case study on Malaysian palm oil. Available via http://r0.unctad.org/infocomm/Diversification/bangkok/onion.pdf. Accessed 15 June 2009

Susila WR (2004) Contribution of oil palm industry to economic growth and poverty alleviation in Indonesia. Jurnal Litbang Pertanian 23:107-114

Suyanto S (2007) Underlying cause of fire: different form of land tenure conflicts in Sumatra. Mitig Adapt Strat Glob Change 12:67-74

Syafriel A (2009) Crude palm oil increases: Fact or fiction? The Jakarta Post 17th June 2009. Available via http://www.thejakartapost.com/news/2009/06/17/crude-palm-oil-price-increases-fact-or-fiction.html. Accessed 15th June 2009

Therville C, Feintrenie L, Levang P (in press) What do farmers think about forest conversion to plantations? Lessons learnt from Bungo district (Jambi, Indonesia). Forests, trees and livelihoods

USDA-FAS (2009) Commodity intelligence report. United States Department of Agriculture-Foreign Agricultural Service (USDA-FAS), Washington DC, USA

Vermeulen S, Goad N (2006) Towards better practice in smallholder palm oil production. Natural Resources Issues Series 5, IIED, London, UK

Wakker E (2006) The Kalimantan Border Oil Palm mega-project. Friends of the Earth Netherlands and the Swedish Society for Nature Conservation (SSNC), Amsterdam

Wilson (2009) Palm oil boycott will hurt impoverished farmers. Available at http://www.abc.net.au/ news/stories/2009/08/05/2646364.htm. Accessed 15 June 2009

WRI (2007) EarthTrends: environmental Information. World Resources Institute (WRI), Washington. DC. Available at http://earthtrends.wri.org. Accessed 15 June 2009

WRM (2001) The bitter fruit of oil palm: dispossession and deforestation. World Rainforest Movement, UK

Zen Z, Barlow C, Gondowarsito R (2005) Oil palm in Indonesian socio-economic improvement: a review of options. Working paper, Australian National University, Canberra, Australia. Available via http://rspas. anu.edu.au/economics/publish/papers/wp2005/wp-econ-2005-11.pdf. Accessed 15 June 2009 